\title{
Peningkatan Ketebalan Epitel Mukosa Bukal setelah Aplikasi Ekstrak Daun Sirih
}

\author{
Winny Yohana, Ame Suciati, dan Myrna Rachmawati \\ Bagian Oral Biologi, Fakultas Kedokteran Gigi, Universitas Padjadjaran, Bandung, Jawa Barat, Indonesia \\ Jl Raya Bandung Sumedang KM 21, Jatinangor; Bandung, Jawa Barat, Indonesia; e-mail: winnyspkga@yahoo.com
}

\begin{abstract}
ABSTRAK
Daun sirih termasuk tanaman herbal yang digunakan untuk bahan alternatif pengobatan, karena kandungannya yang berkhasiat sebagai antimikroba, antiplak, antioksidan, dan mudah didapat serta ekonomis. Penelitian bertujuan untuk mengetahui ketebalan epitel mukosa mulut tikus Wistar setelah aplikasi ekstrak daun sirih. Penelitian bersifat eksperimental pada tiga kelompok yang masing-masing terdiri 9 ekor tikus Wistar. Kelompok pertama sebagai kontrol, kelompok kedua dan ketiga diberikan aplikasi ekstrak daun sirih 15 hari dan 35 hari. Tikus dikorbankan sesuai waktu yang ditentukan lalu dibuat sedian histologis dan pewarnaan HE untuk pengamatan ketebalan epitel. Data ukuran epitel diuji menggunakan uji parametric uji T independen. Hasil penelitian menunjukkan peningkatan ketebalan epitel yang bermakna dicapai oleh kelompok ketiga $( \pm 15,61 \mu \mathrm{m}, p=0,002)$, sedangkan pada kelompok pertama dan kedua tidak terdapat peningkatan ketebalan epitel $(p=0,261)$. Aplikasi ekstrak daun sirih dapat meningkatkan ketebalan epitel mukosa bukal tikus wistar.
\end{abstract}

Maj Ked Gi Ind. Juni 2015; 1(1): hal 21-26

Kata kunci: ekstrak daun sirih, epitel mukosa mulut

\begin{abstract}
Increase in Buccal Mucous Epithelium Thickness after Application of Betel Leaf Extract. Betel leaf (Piper Betle Linn) is a herbal ingredient. It is widely used because of its antibacterial power, anti-inflamatory and antioxidant properties. It is readily available in affordable price. The aim of this study is to determine of buccal mucous epithelium thickness of Wistar rats after the application of betel leaf extract. This was an experimental laboratory research which was performed in three groups of Wistar rats. The first group was the control group. The second and third group were those given betel leaf extract for 15 and 35 days. Each group contained nine rats. The rats were sacrificed at the time determined and made histological slide with HE staining for observation of epithelial thickness. The data of the size of epithelium were tested using independent parametric $T$ test. The result shows a significant increase in buccal mucous epithelium thickness on the third group $(15,61 \mu \mathrm{m}, p=0,002)$. Conversely, there is no increase in buccal mucous epithelium thickness on another group $(p=0,261)$. In conclusion, the increase in buccal mucous epithelium thickness of Wistar rats occurred after the application of betel leaf extract.

Maj Ked Gi Ind. Juni 2015; 1(1): hal 21-26
\end{abstract}

Keywords: betel leaf extract, epithelium oral mucosa

\section{PENDAHULUAN}

Daun sirih (piper betle Linn) merupakan salah satu tanaman herbal yang banyak digunakan untuk alternatif pengobatan, karena kandungannya yang berkhasiat sebagai antimikroba, antiplak, antioksidan, dan mudah didapat serta ekonomis. ${ }^{1}$ Daun sirih mengandung minyak atsiri yang berwarna kuning terang, beraroma kuat, dan rasanya tajam. Kandungan minyak atsiri terdiri dari senyawa hidrokavinol, kavibetol, kavikol, fenol dan eugenol. ${ }^{2}$ Senyawa kavikol mempunyai daya anti bakteri 5 kali lebih kuat dibandingkan dengan fenol. Penggunaan obat kumur 2 kali sehari dapat menurunkan indeks plak. $^{3}$ Penggunaan daun sirih sebagai aplikasi topikal mukosa mulut dengan konsentrasi $4,5 \mathrm{mg} /$ $\mathrm{dL}$ pada mencit dengan pemberian 3 hari sekali selama 35 hari dapat mencegah penurunan $\mathrm{pH}$ plak dan mengurangi insidensi karies gigi. ${ }^{4}$

Pemberian larutan hangat ekstrak daun sirih pada mukosa lambung yang kadar asamnya tinggi, dapat melindungi mukosa dengan cara penebalan epitel mukosa lambung. Lapisan mukosa berperan dalam proses penyembuhan jaringan dengan melindungi dari iritan endogen yang merugikan seperti sekresi asam lambung yang berlebih. ${ }^{5}$ Penelitian lainnya memperlihatkan bahwa daun sirih, selain melindungi mukosa lambung juga dapat mencegah terjadinya ulserasi lambung. ${ }^{6}$ Daun sirih juga dapat menyembuhkan ulserasi lambung yang disebabkan oleh indomethacin pada tikus jantan Sparague-Dawley. ${ }^{7}$ Mukosa mulut mengandung dua lapisan yaitu epitel dan jaringan pengikat 
(lamina propria). ${ }^{8}$ Epitel mulut merupakan lapisan terluar dari mukosa, lamina propria merupakan lapisan serat-serat yang saling terikat dan berfungsi memberikan kekuatan pada epitel. Selsel epitel sebagian besar merupakan sel keratosit, yang apabila mengalami proses pematangan, maka sel tersebut akan terdorong ke permukaan atas. Proses ini berasal dari mitosis yang terjadi pada sel epitel mukosa. ${ }^{9}$ Sel-sel epitel yang terdorong ke lapisan paing atas tidak mempunyai inti dan selnya semakin tipis. ${ }^{10}$ Epitel mukosa mulut merupakan susunan lapisan sel yang berbeda karena mengalami proses mitosis sel yang terus menerus. Setiap sel dalam tubuh mempunyai pola pematangan tertentu, demikian pula mukosa mulut mempunyai waktu pergantian yang khusus. Waktu pergantian jaringan epitel mukosa mulut antara 14 sampai 24 hari. ${ }^{11}$

Berdasarkan uraian di atas maka peneliti tertarik untuk melakukan penelitian bagaimanakah pengaruh aplikasi ekstrak daun sirih terhadap epitel mukosa mulut (tikus Wistar). Tujuan penelitian ini untuk mengetahui ketebalan epitel mukosa mulut tikus Wistar setelah aplikasi ekstrak daun sirih. Hasil penelitian ini diharapkan dapat menambah infomasi yang bermanfaat bagi masyarakat tentang penggunaan ekstrak daun sirih sebagai obat kumur herbal.

\section{METODE PENELITIAN}

Jenis penelitian ini adalah eksperimental laboratoris dengan melihat perubahan yang terjadi pada epitel mukosa mulut tikus setelah diberikan ekstrak daun sirih (Piper betle Linn). Ethical clearance dilaksanakan dengan nomor: 4c /UN6. C2.1.2/KEPK/2013 dan identifikasi tumbuhan dengan nomor: 218/HB/01/2013. Subjek yang digunakan adalah tikus putih jantan dewasa galur Wistar usia 3-4 bulan yang diperoleh dari Laboratorium Farmakologi dan Terapi Gedung Eijkman jalan Eijkman no 38 Bandung. Sampel diambil dengan cara purposive sampling sebanyak 27 ekor yang dibagi tiga kelompok dengan masingmasing terdiri 9 ekor tikus Wistar. Kelompok pertama sebagai kontrol, kelompok kedua dan ketiga diberikan aplikasi ekstrak daun sirih 15 hari dan 35 hari. Objek penelitian adalah epitel mukosa tikus yang disemprotkan ekstrak daun sirih. Pengorbanan dilakukan setelah 15 hari dan 35 hari aplikasi. Jaringan mukosanya dibuat sediaan histologi dengan pengecatan Hematoksilin Eosin.

Alat dan Bahan Penelitian yang digunakan adalah kapas, kertas label, gunting jaringan, syringe, kaca objek dan kaca penutup, mikrotom, stopwatch, mikroskop cahaya, sarung tangan \& masker, daun sirih yang berasal dari Lembang. Tikus Wistar umur 3-4 bulan dengan berat badan sekitar 200-300 gram, akuades, larutan formalin, larutan Hematoksilin dan Eosin.

Pembuatan ekstrak daun sirih (Piper belle Linn) dengan cara daun sirih kering sebanyak 1,5 kilogram dihaluskan menggunakan blender sampai menjadi serbuk kering, lalu dimaserasi filtratnya dengan etanol $70 \%$ selama 3 kali 24 jam. Hasil saringan diuapkan dalam rotary vacuum evaporator dengan suhu $40^{\circ} \mathrm{C}$. Selanjutnya didapatkan ekstrak murni daun sirih kental berwarna coklat, kemudian diencerkan sesuai keperluan.

Sampel penelitian terdiri dari 27 ekor tikus yang dibagi dalam 3 kelompok, kelompok pertama sebagai kontrol hanya disemprotkan akuades ke bagian bukal rongga mulut tikus selama 2,5 menit 2 kali sehari selama 35 hari, kelompok kedua dan ketiga disemprotkan ekstrak daun sirih 15 hari dan 35 hari dengan konsentrasi masing- masing $8 \mathrm{~g} / 100$ $\mathrm{mL}$ dengan cara yang sama.

Tikus dikorbankan pada hari ke-16 untuk kelompok 2 dan pada hari ke-36 untuk kelompok 1 dan 3. Selanjutnya tikus diambil mukosa bukalnya. Epitel dipotong dengan ukuran $0,5 \times 1 \mathrm{~cm}$, kemudian dimasukkan ke dalam larutan formalin. Epitel mukosa dibuat sediaan histologi diwarnai dengan Hematoksilin Eosin.

Pengamatan terhadap sediaan histologi epitel mukosa dengan menggunakan mikroskop cahaya pembesaran 100x. Preparat tersebut diperiksa setiap bagiannya dengan mengamati 5 area 
lapang pandang. Ketebalan epitel diukur dengan mikrometer yang terpasang pada mikroskop cahaya. Pengamatan dengan pembesaran 400 kali bertujuan untuk melihat lebih jelas perubahan jaringan. Data yang diperoleh diberi kode, disusun dalam bentuk tabel, dianalisis menggunakan uji parametrik analisis anova.

\section{HASIL PENELITIAN}

Hasil penelitian dapat diamati di bawah mikroskop dengan keadaan sebagai berikut: Jaringan diambil dari mukosa bukal tikus Wistar kemudian dilakukan pewarnaan $\mathrm{HE}$.

Gambaran mikroskopisepitel epitel mukosa Gambar 1.

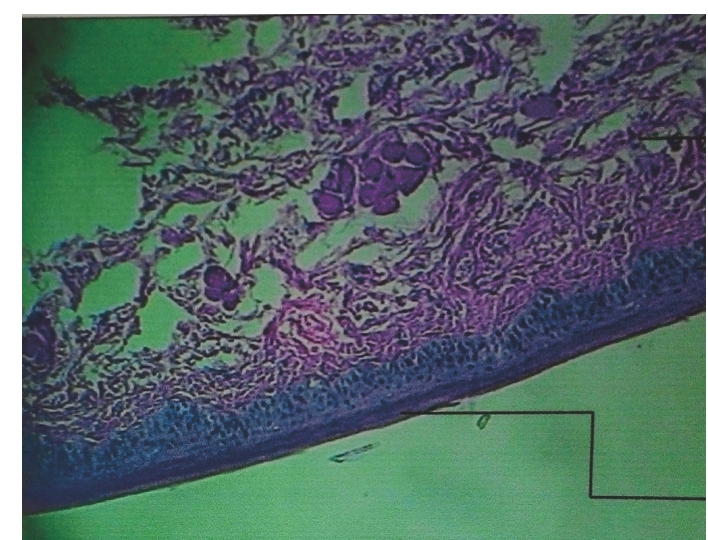

$\longrightarrow$ Jaringan Ikat

Gambar 1. Gambaran Histologis Mukosa Mulut (kontrol) dengan pembesaran 100x

Kelompok kontrol pada mukosa bukal menunjukkan ketebalan epitel rata-rata 3-4 $\mu \mathrm{m}$, keadaan lapisan epitel bersambung diseluruh pemukaan epitel (utuh).

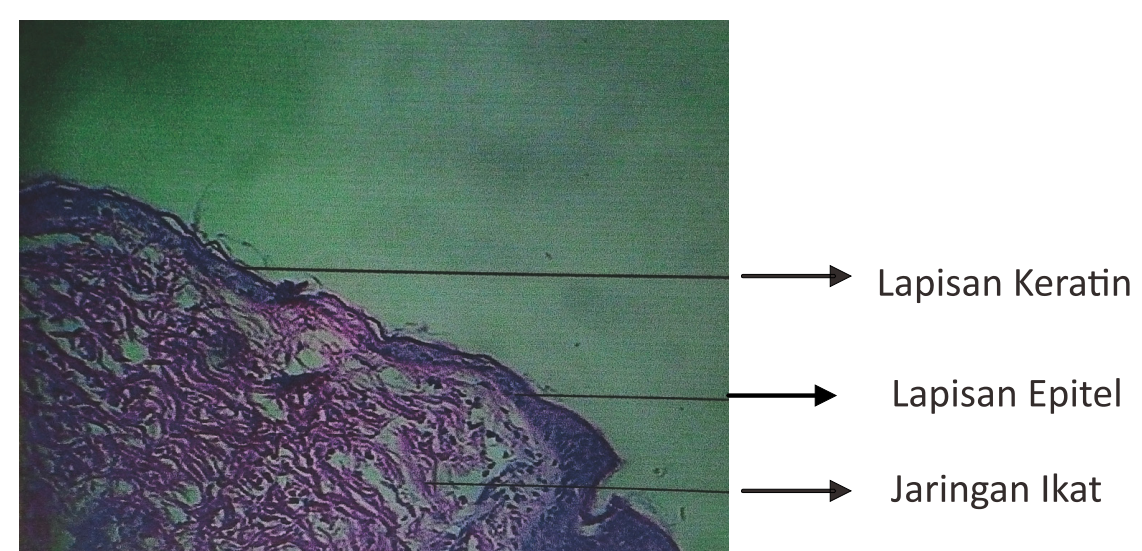

Gambar 2. Gambaran Histologis Mukosa Mulut (perlakuan 15 hari) dengan pembesaran 100x

Kelompok perlakuan 15 hari pada mukosa bukal menunjukkan adanya keratin di atas lapisan epitel dengan ketebalan epitel rata-rata 1-2 $\mu \mathrm{m}$, keadaan lapisan keratin dan epitel bersambung diseluruh pemukaan epitel (utuh). 


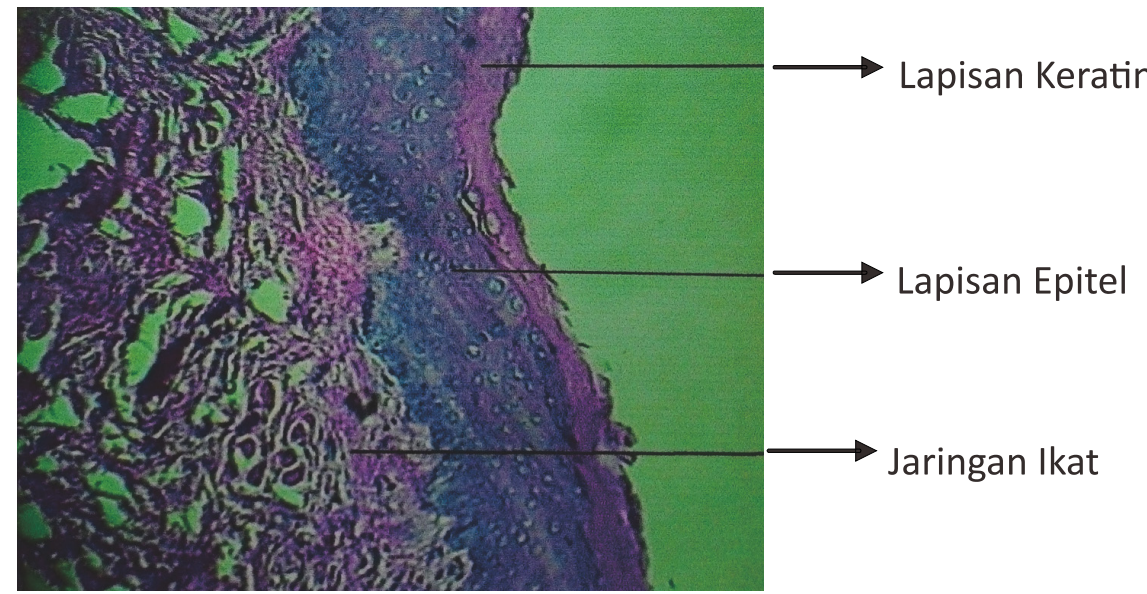

Gambar 3. Gambaran Histologis Mukosa Mulut (perlakuan 35 hari) dengan pembesaran 100x

Kelompok perlakuan 35 hari pada mukosa bukal menunjukkan adanya keratin di atas lapisan epitel yang lebih tebal dibandingkan kelompok perlakuan 15 hari dengan ketebalan epitel rata-rata 12-15 $\mu \mathrm{m}$. Keadaan lapisan keratin dan epitel bersambung diseluruh pemukaan epitel (utuh).

Tabel 1. Hasil Pengukuran Rata-rata Epitel Mukosa Bukal Tikus $(\mu \mathrm{m})$

\begin{tabular}{cccc}
\hline Nomor Sampel & Kontrol & Perlakuan 15 Hari & Perlakuan 35 Hari \\
1 & 3,50 & 2,00 & 19,50 \\
2 & 3,50 & 5,50 & 19,00 \\
3 & 3,50 & 3,50 & 9,00 \\
4 & 3,50 & 1,50 & 10,50 \\
5 & 4,50 & 3,50 & 13,00 \\
6 & 6,50 & 3,50 & 12,50 \\
7 & 5,50 & 5,00 & 33,00 \\
8 & 5,50 & 2,50 & 10,50 \\
9 & 4,50 & 6,50 & 13,50 \\
\hline Rata-rata & 4,50 & 3,72 & 15,61 \\
Standar deviasi & 1,12 & 1,66 & 7,47 \\
\hline
\end{tabular}

Rata-rata ukuran epitel terbesar terdapat pada kelompok perlakuan 35 hari $(15,61 \mu \mathrm{m})$, selanjutnya kelompok kontrol $(4,50 \mu \mathrm{m})$ dan ukuran epitel terkecil dicapai oleh kelompok perlakuan 15 hari $(3,72 \mu \mathrm{m})$.

\section{Analisis Perbandingan Ukuran Epitel pada Tiga Kelompok Uji}

Perbandingan Kelompok Kontrol dengan Perlakuan 15 hari

Berdasarkan hasil uji t di bawah ini, diketahui $p$-value 0,261 , jadi nilai $p>0,05$ artinya tidak ada perbedaan ukuran epitel antara kelompok kontrol dengan kelompok perlakuan 15 hari yang terlihat dari selisih ukuran epitel hanya 0,78 $\mu \mathrm{m}$. Ratarata ukuran epitel kelompok kontrol sedikit lebih besar, akan tetapi perbedaannya tidak signifikan $(p>0,05)$

Tabel 2. Hasil Perbandingan Kelompok Kontrol dengan Kelompok Perlakuan 15 hari $(\mu \mathrm{m})$

\begin{tabular}{l|l|l|l}
\hline Perbandingan & \multicolumn{1}{l}{ Rata-rata } & Simp.Baku & p-value \\
\hline Kontrol & 4,50 & 1,12 & 0,261 \\
\hline $\begin{array}{l}\text { Perlakuan 15 } \\
\text { hari }\end{array}$ & 3,72 & 1,66 & \\
\hline
\end{tabular}


Perbandingan Kelompok Kontrol dengan Perlakuan 35 hari

Berikut disajikan hasil uji $\mathrm{t}$ untuk membandingkan kelompok kontrol dengan kelompok perlakuan 35 hari.

Tabel 3. Hasil Perbandingan Kelompok Kontrol dengan Kelompok Perlakuan 35 hari $(\mu \mathrm{m})$

\begin{tabular}{llll}
\hline Perbandingan & Rata-rata & Simp.Baku & p-value \\
\hline Kontrol & 4,50 & 1,12 & \\
& & & 0,002 \\
\hline
\end{tabular}

Perlakuan $35 \quad 15,61 \quad 7,47$

hari

Berdasarkan hasil uji t pada tabel di atas, diketahui $p$-value 0,002 , artinya nilai $p<0,05$ sehingga terdapat perbedaan ukuran epitel antara kelompok kontrol dengan kelompok perlakuan 35 hari yang terlihat dari selisih ukuran epitel sebesar 11,11 $\mu \mathrm{m}$. Rata-rata ukuran epitel kelompok perlakuan 35 hari lebih besar daripada kontrol. Kesimpulan bahwa terdapat perbedaan yang signifikan $(p<0,05)$ antara kelompok kontrol dan perlakuan 35 hari.

Perbandingan kelompok Perlakuan 15 hari dengan 35 hari

Berikut disajikan hasil uji $t$ untuk membandingkan kelompok perlakuan 15 hari dengan kelompok perlakuan 35 hari.

Tabel 4. Hasil Perbandingan Kelompok Perlakuan 15 hari dengan 35 hari $(\mu \mathrm{m})$

\begin{tabular}{l|l|l|l}
\hline Perbandingan & Rata-rata & Simp.Baku & p-value \\
\hline $\begin{array}{l}\text { Perlakuan 15 } \\
\text { hari }\end{array}$ & 3,72 & 1,66 & 0,001 \\
\hline $\begin{array}{l}\text { Perlakuan 35 } \\
\text { hari }\end{array}$ & 15,61 & 7,47 & \\
\hline
\end{tabular}

Berdasarkan hasil uji $\mathrm{t}$ pada tabel di atas, diketahui $p$-value 0,001 , artinya nilai $p<0,05$ sehingga terdapat perbedaan ukuran epitel antara kelompok perlakuan 15 hari dengan kelompok perlakuan 35 hari yang terlihat dari selisih ukuran epitel sebesar 11,89 $\mu \mathrm{m}$. Rata-rata ukuran epitel kelompok perlakuan 35 hari lebih besar daripada kelompok perlakuan 15 hari. Kesimpulan bahwa terdapat perbedaan yang signifikan $(p<0,05)$ antara kelompok perlakuan 15 hari dan 35 hari.

\section{PEMBAHASAN}

Berdasarkan hasil penelitian terlihat bahwa kelompok kontrol mempunyai ketebalan epitel mukosa rata-rata 4,5 $\mu \mathrm{m}$. Hasil pengamatan pada kelompok perlakuan 15 hari terdapat penipisan epitel mukosa bukal tikus Wistar, adanya lapisan keratin pada kelompok perlakuan 15 hari yang lebih tipis dibandingkan kontrol kemungkinan disebabkan waktunya baru 14 hari sedang terjadi proses proliferasi sel/pergantian sel pada waktu tersebut yang berakhir pada hari ke-24. Sesuai dengan pernyataan bahwa setiap sel dalam tubuh mempunyai pola pematangan tertentu dan mempunyai waktu khusus pergantian sel. Demikian pula mukosa mulut mempunyai waktu pergantian sel epitel mukosa antara 14 sampai 24 hari. ${ }^{11}$

Kelompok perlakuan 35 hari terlihat bahwa epitelnya lebih tebal dibandingkan kontrol. Hal ini diduga akibat kandungan yang terdapat dalam daun sirih yang mengakibatkan mitosis yang berlebih. Kemungkinan merupakan efek proteksi terhadap sel epitel mukosa. Penebalan lapisan epitel dapat disebabkan adanya kandungan alilpirokatekol yang memiliki antioksidan, sehingga tubuh memproduksi mukus dan terjadi penebalan mukus pada mukosa yang bersifat sitoprotektif.6,7 Epitel gepeng berlapis mempunyai permeabilitas pertahanan jaringan yang efektif pada lapisan superfisial epitel mukosa. Epitel mukosa bukal pada keadaan normal hanya mempunyai lapisan tipis keratin. Penebalan epitel nonkeratin pada mukosa bukal diduga merupakan respon fisiologis terhadap iritan. ${ }^{12}$ Pergantian jaringan epitel terjadi pada permukaan sel epitel yang terus menerus mengalami kematian sel. Epitel mempunyai daya pertahanan yang tinggi terhadap benda asing atau iritan yang menyerangnya. Adanya hyperkeratosis, odem, kemerahan pada mukosa diduga sebagai respon tubuh terhadap benda asing yang bersifat sitotoksik ekstrak daun sirih terhadap sel epitel. ${ }^{13}$ 


\section{KESIMPULAN}

Berdasarkan hasil penelitian, dapat disimpulkan bahwa ekstrak daun sirih dapat meningkatkan ketebalan epitel mukosa mulut tikus Wistar.

\section{DAFTAR PUSTAKA}

1. Datta A, S Ghoshdastidar, $M$ Singh. Antimicrobal property of Piper betle $L$. against clinical isolates of bacteria. International Journal of Pharmaceutical Sciences and Research. 2011; 2(3): 104-9. Available online at http://www.ijpsr.info (cited 2012 May).

2. Vikash C, T Shalini, NK Verma, DP Singh, SK Chaundhary, R Asha. Piper betel Phytochemistry, traditional use \& pharmacological activity a review. International Journal of Pharmaceutical Research and Development. 2012; 4(04): 216-23. Available online at http://www.wijprd.com (cited 2013 January).

3. Ardianti GM. Efektivitas ekstrak daun sirih sebagai obat kumur terhadap penurunan plak indeks studi di wilayah kerja puskesmas kaliori Rembang. 2011. Available online at http:// www.lib.unnes.ac.id/8000/ (cited 2012 july).

4. Astuti HD, Praba FW, Ayu IY, Roeslan BO, Sjahruddin L. Efek aplikasi topikal laktoferin dan Piper betle Linn pada permukaan mukosa mulut terhadap perkembangan karies. Majalah IImiah Kedokteran Gigi. 2007; 22(1): 28-31.

5. Rahmatullah M, IJ Mukti, AKMF Haque, Md AH Mollik, P Kanta, Jahan R, Chowdhury $\mathrm{MH}$, Taufik R. An ethanobotanical survey and pharmacological evaluation of medicinal plants used by garo tribal community living in Netrakona district, Bangladesh. Advances in Natural and Applied Sciences. 2009; 3(3): 402-18.
6. Majundar B, SR Chaundari, A Roy. Potent Antiulcerogenic activity of ethanol extract of leaf Piper betle Linn by antioxidative mechanism. Indian Journal of Clinical Biological Chemistry. 2002; 17: 49-57. Available online at http:// www.link.springer.com/article/ (cited 2013 january).

7. Bhattacharya S, D Banerjee, AK Bauri, $S$ Chattopadhyay, SK Bandyopadhyay. Healing Property of the Piper betle phenol, Allylpyrocatechol against indomethacininduced stomach ulceration and mechanism of action. World Journal Gastroenterology. July 2007; 13(27): 3705-13 Available online at http:// www.ncbi.nlm.nih.gov/pubmed/17659730 (cited 2013 june).

8. Markiewicz MR, JE Margarone III, G Barbagli, FA Scannapieco. Oral Mucosa Harvest an Overview of anatomic and biologic considerations, Update series 5, NY: Elsevier, 2007; 179-87. Available online at http://www. sciencedirect.com (cited 2012 October).

9. Fawcett, DW. Buku Ajar Histologi Ed. 12, Jakarta: EGC, 2002; 499-515.

10. Shojaei AH. Bucal mucosa as route for systemic drug delivery a review. J. Pharm Pharmaceut Sci 1998; 1(1): 15-30 Available online at http://www.ualberta.ca (cited 2012 May).

11. Bath-Balogh M, MJ Fehrenbach. Dental Embriology Histology and Anatomy, $2^{\text {nd }}$ ed., America: Elsevier Inc, 2006; 127.

12. Squier CA, K Brogden. Human Oral Mucosa: Development, Structure and function, Oxford: Wiley-Blackwell.1991; 19-41.

13. Fujisawa S, N Okada, E Muraoka. Comparative effect of Eugenol to bis eugenol on oral mucous membranes. Dent Mater J, Sept 2001; 20(3): 237-42. Available online at http://www.ncbi. nlm.nih/ grov/pubmed/11806158 (cited 2013 March) 